\title{
FARM MANAGEMENT METHODS TO CONTROL PASTURE PESTS
}

\author{
R. A. FRENCH
}

Insect Control Section, M inistry of Agriculture and Fisheries, Christchurch

\section{Abstract}

It is suggested that methods of stock and pasture management integrated with the farm management programme could reduce both pasture pest populations and their effect on farm stock production.

\section{INTRODUCTION}

SINCE: 1970 when the use of DDT was prohibited there has been much concern about the possible increasing effect that pasture pest damage will have on production of meat, wool and milk in New Zealand. In some areas of New Zealand it has been blamed as the limiting factor for increased farm output (Wilson, 1974; Ellett, 1974).

The high cost and transient nature of the insecticides used for pasture pest control in the post-DDT era has led to considerable efforts by entomologists to find alternative methods of control (Little, 1975). There has been a marked swing towards research aimed at management and cultural forms of pest control.

This paper outlines a number of management procedures that have been and are being developed to control or reduce the effect of pasture damage caused by two important pasture pests, grass grub (Costelytra zealandica) and porina (W'iseana spp.). The techniques are applicable mainly to the Canterbury flat land region. In some cases the methods have not been scientifically proven although active research is being carried out on most. All the tactics mentioned, however, have been attempted in the field by farmers. Where quantitative data are lacking, preliminary obscrvations have shown that all can be effective against the pests in some circumstances. A summary of possible tactics for combating the effects of both grass grub and porina is given in Table 1 .

\section{DISCUSSION}

For grass grub, deep cultivation in late September/early October, the use of resistant pasture species - e.g., lucern and stock management have all been found to reduce insect numbers (Kain and Atkinson, 1970). 
TABLE 1: SUMMARY OF POSSIBLE TACTICS TO REDUCE THE EFFECTS OF GRASS GRUB AND PORINA DAMAGE

Grass GRUB

1. Deep ploughing during the pupal stage.

2. Use of resistant species - e.g., lucerne.

3. Mob-stocking with sheep during winter.

4. Mob-stocking with cattle in autumn.

5. Heavy rolling in spring.

6. Irrigate and heavy roll in early winter.

7. Apply superphosphate in autumn rather than spring.

$\mathcal{E}$. Use specialist summer and/or winter forage crops to compensate for pasture damage.

\section{PORINA}

1. Mob-stocking with sheep during the surface dwelling larval stage.

2. Use of resistant or tolerant grass species $-\boldsymbol{e}$.g.. cocksfoot.

3. Cultivate infested pasture and sow Tama in autumn.

4. Use infested pasture as a winter runoff. Feed out hay in damaged areas to 'help re-seeding.

5. Direct drill grass into damaged patches in spring.

Some of the work of Kain and Atkinson ( 1970) has been repeated in Canterbury. Deep ploughing (down to $20 \mathrm{~cm}$ ) during the pupal period (September-October) has been very successful to date (Table 2). This tactic could be used in conjunction with

TABLE 2: DEEP PLOUGHING TO REDUCE GRASS GRUB NUMBERS

(Ruapuna soil type)

\begin{tabular}{ccc}
\hline $\begin{array}{c}\text { Date of Deep } \\
\text { Ploughing }\end{array}$ & $\begin{array}{c}\text { Average Crass } \\
\text { Aug.- } 1973\end{array}$ & $\begin{array}{c}\text { Grub } \\
\text { Number per } m^{2} \\
\text { Aug. } 1974\end{array}$ \\
\hline Oct. 1972 & $29 \mathrm{bB}$ & $48 \mathrm{cC}$ \\
Nov. 1972 & $28 \mathrm{bB}$ & $108 \mathrm{bBc}$ \\
Feb. 1973 & $170 \mathrm{aA}$ & $154 \mathrm{abAB}$ \\
Unploughed pasture & $162 \mathrm{aA}$ & $197 \mathrm{aA}$ \\
\hline
\end{tabular}

summer forage crops and later sown crops such as oats. For porina, intensive' mob-stocking with sheep for a short period in late spring (in Canterbury) (French, 1973) reduces the surface dwelling larval population densities and subesquent pasture damage, i.e.

\section{Mean $\mathrm{N} 0$}

Surface D welling Larvae $/ m^{2}$

Mob stocked with sheep in late December 164

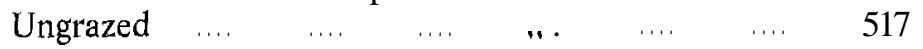

The principle of compensating for damage by growing extra herbage on undamaged areas should also be considered, For 
TABLE 3: THE USE OF TAMA RYEGRASS TO COMPENSATE FOR GRASS GRUB DAMAGE IN CANTERBURY (Ruapuna soil type)

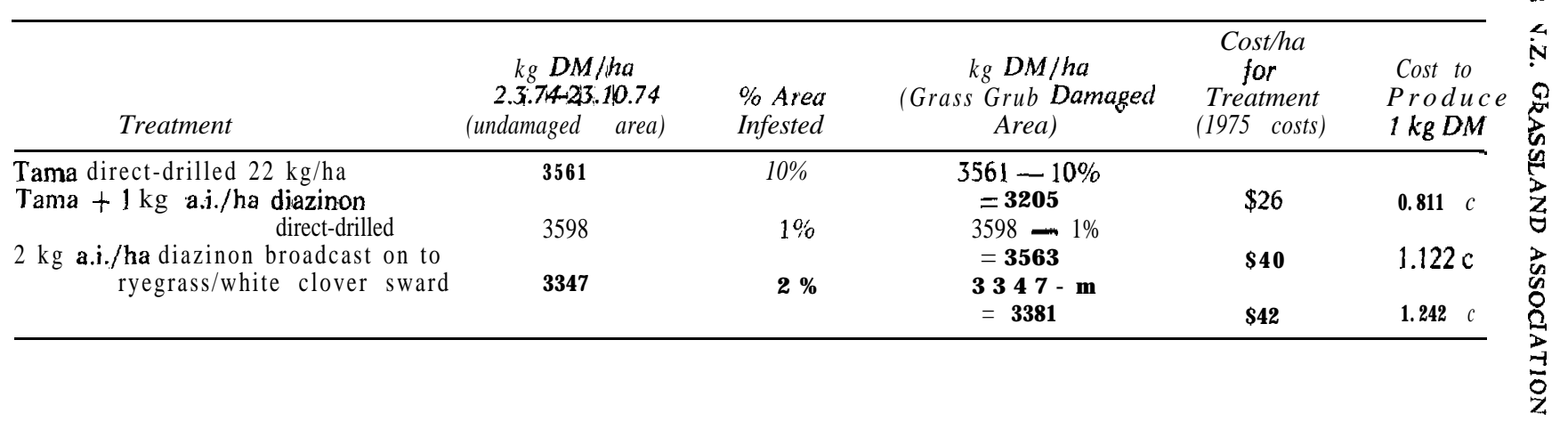


example, direct drilling Tama can compensate for damage by producing extra grass over and above that normally obtained from winter pasture. The cost can be comparable with the use of insecticide without the disadvantages of the latter - e.g., insect resistance, environmental pollution, destruction of beneficial organisms. The principle is illustrated in Table 3.

Obviously, the economic climate and the area damaged will influence the farmer's decision and the course of action. The principle, however, could be extended to include summer cropping - e.g., maize on previously damaged pasture. For example, a rotation of maize-Tama-spring sown new grass (with the grasses direct drilled), after a deep ploughing in spring to destroy the insect population, may have a better gross margin than the use of insecticide. The costs of the whole operation could be more than offset by the extra stock production made possible by higher dry matter production. Insecticides, applied to pasture, cannot bring about extra grass production in the sense that fertilizers do. By reducing insect numbers, insecticides merely allow the normal potintial pasture growth to be released.

For the hill country farmer, pasture pest damage is potentially more serious. He does not have the same flexibility in management as the flat land farmer. First year results, however, from a survey of management practices used against grass grub in the Ashburton county, have indicated that such factors applicable to hill country management as cattle grazing in autumn, mobstocking sheep in winter, and autumn application of superphosphate show promise. If these preliminary statistical correlations can be repeated in the subsequent years of the study, each factor will then be intensively researched. If any one is found to be a practical means of pasture pest control, it will be further evaluated by means of a pest management programme carried out, cither on a commercial farm or an experimental farmlet.

It is not intended to imply that farm management will be the panacea for insect control. Methods of pest control in the presence of pasture pest damage imply making decisions based on a different set of data than if the pests are absent. As maay factors as possible should be considered and an order of priority determined. Consideration should be given to pasture and stock management as well as the financial position of the farm. For example, greater pasture utilization may be the highest priority on the farm regardless of insect damage to pasture. This may mean emphasizing a change of tactics regarding stock management, paddock size and breed of animal. No matter what method of pasture pest 
control is being considered, be it insecticide or management, the cost/benefit ratio should be calculated and considered before implementing any decision, especially in areas where profitable farming is a doubtful proposition even under the most favourable conditions, ‘. This essentially means considering pasture'pest damage as a cost of production, as is fertilizer for grass growth, or drench to destroy internal parasites of stock. Only if the benefit exceeds the cost by a profitable margin should any control procedure be used. The exception to the rule may occur if the aspect of insurance against damage is being considered. This may entail growing or obtaining extra feed in anticipation of pasture damage. The same pragmatic cost/benefit approach should still apply albeit, however, on different conditions.

\section{CONCLUSION}

It is concluded that, to minimize the effect of pasture pest damage on both farm profitability and stock production, tactics should be design\&d to suit the individual farmer. his farm management policy and the local climate and environment. Essentially, this means careful integration of all available approaches previously mentioned. It is here that the role of the farm advisory officer is very important. He should be fully aware of the latest entomological data available, especially on methods of damage assessment, have the ability to critically examine pasture pest probms in relation to the overall farm management and the ability to advise on and integrate the appropriate control tactics.

Finally, it is the writer's opinion and experience in Canterbury that, because of the visual and hence emotional impact of pasture pest damage, many farmers find it very difficult to tolerate any signs of damage whatsoever. They place a very high priority on total eradication at any cost. Until this unrealistic' and costly attitude is replaced by more realistic farm management strategies, pasture pest damage will continue to dominate the pastoral farming scene.

\section{REFERENCES}

Ellett, T. R., 1974. Intensive town milk production. Proc. N.Z. Grassld Ass., 35 (2): 175-81.

French, R. A., 1973. Mob stocking to beat porina. N.Z. /l Agric., 126 (2): 21-3.

Kain, W. M.; Atkinson, D. S., 1970. A rational approach to grass grub control. Proc. 23 rd N.Z. Weed \& Pesi Control Conf.: 180-3.

Little, C., 1975. Pasture insect pest research (1). N.Z. Farmer, 96 (4): $12-5$.

Wilson, B., 1974. Porina — nobody knows enough about it. Ibid., 95 (13): 8-10. 